Saeculum Christianum

vol. XXII (2015)

pp. $248-255$

\title{
DARIUSZ MISZEWSKI*
}

Wrocław

\section{INTERNATIONAL ORDER IN THE IDEOLOGY OF THE KNIGHTS' ORDER OF CROSS AND SWORD DURING THE SECOND WORLD WAR}

The Knight's Order of Cross and Sword was founded before the outbreak of World War II by certified captain, pilot Wojciech Polesiński who devoted his life to merging Catholicism and patriotism in public life ${ }^{1}$. He cooperated with academic circles of Sodality of Our Lady and Catholic Action ${ }^{2}$. In the latter half of the thirties of the 20th century he was actively operating in the army attempting to influence it ideologically and religiously. He struggled for the ideological and moral upbringing of a soldier - defender of faith, people and Polish nation. He published his views on this matter in a booklet entitled „A Polish soldier and a German soldier. An analysis of martial values" (1939) which was later translated to various foreign languages. German embassy in Warsaw and German press protested against its publication and demanded its withdrawal from circulation and printing ${ }^{3}$.

After the activities of The Knight's Order of Cross and Sword were prohibited in 1938 by the army authorities he opened his movement to civilians. Cpt. W. Polesiński addressed and reached the public opinion by writing and publishing articles in e.g. „Przegląd Lotniczy [tn - Pilot's Digest]” and „Polska Zbrojna [tn - Armed Poland]” magazines. He also organized public readings and presentations. His social and religious movement garnered significant response among populace owing to the „O mocnego człowiek w Polsce [tn - For a Strong Man in Poland]” pamphlet (1938) ${ }^{4}$. In the March of 1938 „Krzyż i Miecz [tn - Cross and Sword]" monthly magazine, which soon became the unofficial press organ of the Knight's Order of Cross and Sword and was initially printed in the apartment of Zbigniew Kurzyna, started publication. Additionally, in the April of 1939, „Biuletyn Dozbrojenia Moralnego Narodu [tn - Newsletter for Moral Strengthening of the Nation]" started publication as well. His movement intended to pursue teachings of Christ in public life, first in Poland and then across the borders. Members of the Knight's Order of Cross and Sword were supposed to become moral elite in political and social life. Poland was to propagate international cooperation based on the rules of Christian morality. He deemed Germany and USSR and

\footnotetext{
Translated by Spektra Sp. z o.o.

S. Jarmulski, Władystaw Polesiński (1906-1939), Polski Słownik Biograficzny, t. 27, Wrocław 1982, p. 292.

2 T. Tarnogrodzki, R. Tryc, Polskie organizacje konspiracyjne w kraju w latach 1939-1945, „Wojskowy Przegląd Historyczny", 1966, nr 4, p. 270.

3 S. Jarmulski, Władystaw Polesiński (1906-1939), p. 293.

4 J. Herbich, Człowiek mocny Bogiem. Kapitan pilot Władysław Polesińnki, Warszawa 2006, pp.78-79; see also D. Pater, Zakon Krzyża i Miecza. Wołanie o mocnego człowieka w Polsce, „Pro Fide Rege et Lege”, 2006, no. 56.
} 
their totalitarian ideologies ${ }^{5}$ to be the enemies of Christianity and Poland. The public activism of Cpt. W. Polesiński was met with positive reception on the part of Catholic Church and public opinion and aversion and antipathy of the government leadership as well as left-wing and right-wing opposition parties ${ }^{6}$.

By the end of the August of 1939 Cpt. W. Polesiński was assigned to the Air Force and AntiAir Defense Command of Modlin Army where he led intelligence team? 7 In the September of 1939 he led air reconnaissance of Warsaw. Since the 10th of September 1939 he has been giving passionate daily speeches to defenders and residents of the capital, motivating and cheering them on to fight against Germans as well as condemning the barbaric bombardment of Warsaw. He usually appeared on stage just after the speeches of the president of Warsaw, Stefan Stażyński (1934-1939). Cpt. W. Polesiński fell during the reconnaissance by fire on the 16th of September 1939 in the vicinity of Warsaw. His resting place is unknown. He orphaned his wife, teacher Janina née Truszkowska, and son Władysław Gerard Polesiński born in 1936.

Conspiratorial operations of the Knight's Order of Cross and Sword begun in the spring of 1940 with its cells operating primarily in Warsaw and Poznań. It was the result of the dispersion of its few members after the defensive war in the September of 1939 and the tragic death of $\mathrm{Cpt}$. W. Polesiński in combat. The underground resistance organization consisted of: second lieutenant aeronautical engineer Jan Herbich (codename „Godzimierz”), Zygmunt and Ludwik Kaczanowscy, Ludwik Kłobukowski, Zbigniew Kurzyna, Władysław Niedenthal, Stanisław Popiel and Saturnin Jarmulski. Priest Jan Zieja also cooperated with the organization. Members of the Knight's Order of Cross and Sword operated within structures of Union of Armed Struggle and Home Army. They fought and died for the independent Catholic Poland: Z. Kaczanowski (Oświęcim), S. Popiel (Majdanek 1943), L. Kłobukowski (Pawiak 1943), L. Kaczanowski and W. Niedenthal (Warsaw Uprising 1944) and after the fall of Warsaw Uprising in the October 1944 Z. Kurzyna was captured and imprisoned by German forces 8 . A part of members of the Order was active in other underground resistance organizations during the wartime. For instance, major Jan Włodarkiewicz (codename „Darwicz”, a member of UoAS/HA and commander of „Wachlarz [tn - the Fan] organization) formed Secret Polish Army in cooperation with second lieutenant Witold Pilecki (codename „Witold”). Priest Jan Zieja was also one of its members.

During the period of resistance and conspiracy „Polska Zbrojna Moralnie [tn - Poland Armed in Morals]" was the press organ of the Knight's Order of Cross and Swords. Oneday newspapers „O Polskę Chrystusową [tn - For Christ's Poland]” and „W służbie [tn - In service]" were also published ${ }^{9}$. The organization fully supported the operations of Polish underground because they considered influencing Polish soldiers ideologically as one of its primary objectives. In turn, it regarded government-in-exile with criticism for ideological reasons and due to the Polish-Russian agreement ${ }^{10}$ entered into in the July of 1941. The

\footnotetext{
S. Jarmulski, Władystaw Polesiński (1906-1939), p. 292; J. Herbich, op. cit., p. 50.

S. Jarmulski, Prośba o materiaty, „Tygodnik Powszechny”, 2 IX 1973, nr 35, p. 4.

S. Jarmulski, Władysław Polesiński (1906-1939), p. 293; J. Herbich, op. cit., pp. 62-67.

J. Herbich, op. cit., p. 22

Ibidem, p. 22.

10 Archiwum Akt Nowych [tn - Archive of New Files], Delegatura Rządu RP na Kraj [tn - Government Delegacy for Poland], Departament Spraw Wewnętrznych [tn - Internal Affairs Department], signature 202/II-22, 1636, Organizacja Zakon Krzyża i Miecza, report no. 34/42, 5 II 1942, p. 18.
} 
organization maintained good relations with Catholic and cross-party Front Odrodzenia Polski [tn - Poland's Restoration Front] members of which, e.g. Zofia Kossak-Szczucka, contributed articles to „Polska Zbrojna Moralnie” magazine. During the war ideological schism occurred in the organization: whether to push for bigger social and political inclusivity or to remain an elitist social and cross-party movement with strong emphasis on ideological values ${ }^{11}$. In 1942 the majority of members of the Knight's Order of Sword and Cross entered The Union led by Jerzy Braun (codename „Rogowski”) ${ }^{12}$ which was established in the June of 1940 with the object of consolidating conspiratorial groups based on Christian-democratic ideology. In the February of 1943 the Union combined with Labour Party.

The history of the Knight's Order of Cross and Sword during the World War II is little known. We do possess slightly more information about its activities in the pre-war period. The publications available on this subject were listed in footnotes. In my research on the subject of history of the Order I used recollections of its members and rather scarce archive materials, mainly press, gathered in the National Library in Warsaw.

As a Catholic-national organization combining religion and patriotism the Knight's Order of Cross and Sword believed that even the barbaric policy of Germany and USSR aimed against Poles do not relieved them from the principles of Catholic morality and obligation to serve homeland militarily and through charity ${ }^{13}$. He struggled and pushed for the restoration of Poland which would lead post-war Europe not only as a nation strong in terms of power and might but also in terms of Catholic morality. In his opinion Poland could not be restored solely on the grounds of Roman Dmowski's or marshal Józef Piłsudski’s political and territorial conceptions. It would be best if it had been a fusion of these two notions which were ,national but not Catholic, insincere towards God" with Christian ethics. These conceptions must have been supplemented with morality and social teachings of the Catholic Church ${ }^{14}$. The Poland restored in 1918 fell in the September of 1939 because it was based solely on the foundations of purely temporal political programmes. The Divine providence tested Poland during the World War II putting it through a peculiar purgatory of sorts. In the face of this historical test he urged for fraternity among soldiers, solidarity within nation and to follow the "love thy neighbor" principle towards the political adversaries ${ }^{15}$.

The Knight's Order of Cross and Sword criticized National Camp for propagating primacy of nationalism before Catholicism. He held that Catholicism and nationalism should go handin-hand in Poland. According to him love for homeland did not interfered with Catholic morality. Nationalism could not oppose the Christian morality because the road to National Poland leads through nationalism [the road] to Catholic Poland leads through Catholicism, [the road] to Great Poland leads through Catholicism and nationalism ${ }^{16}$. Without the Christian morality nationalism leads to totalitarianism and materialism, ideologies responsible for the outbreak of World War II and crimes against humanity. „Polska Zbrojna Moralnie” magazine proclaimed that Us, Poles, through our geopolitical footing, our tradition and

11 T. Tarnogrodzki, R. Tryc, op. cit., p. 270.

12 A.K. Kunert, Ilustrowany przewodnik po Polsce podziemnej 1939-1945, Warszawa 1996, p. 461; J. Skwara, Unia, vol. 17, Encyklopedia Białych Plam, Radom 2006, p. 260.

13 Kim jesteśmy, do czego dą̇ymy, „Polska Zbrojna Moralnie”, 20 X 1941, no 1, pp. 1-2.

14 Rola katolicyzmu w odbudowie Polski, „Polska Zbrojna Moralnie”, 20 X 1941, no. 1, p. 6.

15 Redakcja; Ku jedności, ,Polska Zbrojna Moralnie”, listopad 1941, no. 2, pp. 1-2, 3-6.

16 Katolicyzm i nacjonalizm, „Polska Zbrojna Moralnie”, listopad 1941, no. 2, p. 11. 
national character, are particularly predestined to embark on a mission of the restoration of Catholic nations and unification of Slavic people ${ }^{17}$. Poland's Restoration Front fully agreed with the moral orientation of „Polska Zbrojna Moralnie”.

In 1941 Knight's Order of Cross and Sword published a booklet „O Polskę Chrystusową” the contents of which it published in the consecutive issues of its press organ. There it presented its vision of Poland and the rules Poland should follow after regaining independence ${ }^{18}$.

In terms of social relations the Order advocated national solidarity in place of personal, group or class egoism ${ }^{19}$. The order based political and economical systems on the social teachings of the Catholic Church, vocational and economical self-governance, respect of personal freedom and dignity and the protection of hired labor $^{20}$. The political system could not be materialistic, totalitarian and anarchic as was, in his opinion, liberal democracy.

In the September of 1939 Poland suffered defeat due to its spiritual and material weakness. In 1920 ideologically strong Polish nation was able to halt the expansion of Soviet Russia to Poland and Western Europe. However, during the World War II Poland could not restrict itself to the passive role of a bulwark of Christianity protecting itself and central Europe nations from materialistic and imperialistic powers. Poland had to take great initiative worthy of the Poland of Chrobry and Jagellons and fight for the Christian Europe. „Polska Zbrojna Moralnie" persuaded that during the war imperialistic and materialistic nations, Hitler's anti-Christian Germany and communist USSR in particular, mutually devastated and ravaged each other. Post-war world should arise as a new social order based on Christ's timeless plan concerning social love ${ }^{21}$. The magazine encouraged the view that it was the departure from moral principles in internal and international relations that led to the next barbaric war rather than the Treaty of Versailles or some form of national system ${ }^{22}$. Poland and Lithuania founded political, economical and cultural greatness of Polish-Lithuanian Commonwealth on the foundation of Christianity. The Poland of Jagiellons would not be a powerhouse if it not treated neighboring nations according to the rules of Christianity. „Polska Zbrojna Moralnie” claimed that the post-war Poland will achieve greatness not through national egoism or geopolitics but through justice, freedom, morality and basing international relations on the universal Christian rules ${ }^{23}$.

The war accompanied humanity since its beginnings bringing death, suffering and devastation. The opposite of war was peace comprehended as a state in which people live, work and create together in harmonious cooperation, a natural destiny of nations ${ }^{24}$ Because the internal and external war is not an inevitable fate of humanity people of all nations, bound by universal fraternity, should strive together to establish common universal ideas and work to realize them ${ }^{25}$. It were the false national prophets - contemporary leaders believing

\footnotetext{
17 Pod sztandarem Chrystusa, ,Polska Zbrojna Moralnie”, 24 XII 1941, no. 3,p. 3.

18 Od Redakcji, ,Polska Zbrojna Moralnie”, 31 VII 1942, nos. 5-6, p. 1.

19 Istota rewolucji społecznej; System czy człowiek, „Polska Zbrojna Moralnie”, march 1942, no. 3, pp. 1-6.

20 Praca i własność, „Polska Zbrojna Moralnie”, march 1942, no. 3, pp. 6-10; O Polske praworzadna; Państwo w stużbie idei, „Polska Zbrojna Moralnie”, april 1942, no 4, pp. 1-7, 8-10.

21 O nowy cud nad Wista, ,Polska Zbrojna Moralnie”, 20 X 1941, no. 1, pp. 10-11.

22 W Betlejem odrodzenie, „Polska Zbrojna Moralnie”, 24 XII 1941, no. 3, p. 7.

23 Doką idziemy?; Na dziejowym szlaku, „Polska Zbrojna Moralnie”, 31 VII 1942, nos. 5-6, pp. 1-3, 8-10.

24 Pokój czy wojna, „Polska Zbrojna Moralnie”, February 1942, no. 2, p. 9.

25 Ibidem, p. 10.
} 
themselves to be embodiments of ideals and architects of communal will - who stupefied the entire nations under the pretence of national and social cause and who rejected all rules of morality $^{26}$. To achieve their goals these leaders used the fact that man was not born good and only saw goodness of others after receiving Christ's teachings. The leaders of materialistic ideologies destroyed their people's morality towards other groups and nations using human greed, pride and lust for destruction, conquest, reign and violence.

The war was just and justified when waged to protect order and restore the rule of law and peace. Justness and fairness of war did not depend on who started it. A nation should not wait to be assaulted but should pre-emptively attack themselves in order to capture and seize all the advantages a surprise attack confers if an enemy was widely known to be preparing for war and it was obvious that he was a threat to people and nations. Pre-emptive attack should be conducted in defense of law, morality and justice and shirking from the responsibility to defend these values constituted a crime ${ }^{27}$. The outbreak of World War II was a moral failure of Europe because it was unable to defend and uphold the laws and rules Europe itself imposed in the name of peace. The duty of Europe during World War II was to eradicate two great enemies of mankind - German Hitlerism and Soviet communism. Adhering to materialistic and totalitarian ideologies Germany and USSR caused World War II in the name of national and class egoism. For this they should face punishment, as the nations and as the states ${ }^{28}$.

The war and the assault were also justified when conducted in order to protect national minorities living on the territory of other country, if said minorities were persecuted, and in order to aid an unjustly assaulted country. Initiating a war, even in defense of the rule of law, should simultaneously be a thoroughly cautious and careful act because peace was far too precious to relinquish it rashly. The sole belief that fairly established law was endangered or infringed did not constitute a valid and adequate casus beli. The rule of law must have been permanently and irrevocably endangered and the need to defend it must have arisen. The importance of values leading to the outbreak of war must have outweighed the damages and losses. The basic premise was to protect and defend universal rules and laws by peaceful means. If the peace was to be permanent it should have been just and commonly accepted by the participants of the international relations ${ }^{29}$.

„Polska Zbrojna Moralnie” wrote what follows on the subject of international order: ,the genuine peace and genuine order must be founded on three components: justice, love, and $m i g h t^{30}$. In the international relations justice was interpreted as respecting moral and material rights of nations. But according to the magazine small and great nations were entitled to different rights. Small nations had the right to culture, language, religion and development but not always right to own independent state because they could exist and operate under military, economical and political protectorate of greater nations. Even if small nations were entitled to national independence they should take into consideration the leadership of greater nations in the aspect of their security. As an example „Polska Zbrojna Moralnie” magazine

\footnotetext{
26 Pod sztandarem Chrystusa, „Polska Zbrojna Moralnie”, 24 XII 1941, no. 3, p. 6; W 79. rocznice powstania stycz-niowego, „Polska Zbrojna Moralnie”, 23 I 1942, no. 1, p.4; Pokój czy wojna, „Polska Zbrojna Moralnie”, February 1942, no. 2, p.10.

27 Pokój czy wojna, „Polska Zbrojna Moralnie”, February 1942, no. 2, pp.10-11.

28 Rok 1942; W 79. rocznice powstania styczniowego, „Polska Zbrojna Moralnie”, 23 I 1942, no 1, pp. 1-2, p. 4.

29 Pokój czy wojna, „Polska Zbrojna Moralnie”, February 1942, no. 2, p.12.

30 Pokój narodom dobrej woli, „Polska Zbrojna Moralnie”, 24 XII 1941, no. 3, p. 9.
} 
presented the case of Belorussian nation which was not yet ready for an independent state, similarly to numerous nations living in the territory of Russia. Probably Byelorussia would in time mature enough to the role of independent state but at this moment these lands have neither grounds nor rights to exist as an independent state entity. The Belorussian nation certainly existed but it did not possess attributes necessary to form a state. Naturally the magazine listed Poland among great and leading nations.

„Polska Zbrojna Moralnie” magazine reasoned that this mosaic of smaller and bigger state entities must form harmonious patterns. Nations destined to lead other nations must exist. Their greatness, culture, tradition and geographical placement - all these factors invoke their right to take the position of power and lead others. Nations united in international blocs were connected by a number of political, economical, military and cultural interests but this does not mean that conflicts and disagreements did not occur between them. The role of the leading nation was to adjudicate this clashes and disputes and reconcile feuding parties. For the leading nation the right to rule was not an egotistical privilege but the obligation and responsibility to care of the weak and the interest of the whole. Therefore, in adjudicating and arbitrating foreign disputes and clashes a leading nation has to possess a highly developed self-criticism, impartiality and the ability to keep own ambitions in check. „Polska Zbrojna Moralnie” cautioned that the greatest threat to the leading nation was the excessive nationalist sentiment. Nationalism constituted an irreplaceable component of power of a nation state but it could also be used against other nations encroaching on world peace. Such „excess” was characteristic to Hitler's Germany and USSR which apart from communism expressed nationalist tendencies in internal and international politics. „Polska Zbrojna Moralnie" magazine emphasized that Poland, fighting for establishing fair, just and moral order in Europe, had to take into consideration the Soviet nation's right to independence or otherwise the sense of wrong will not be alleviated and foundations for permanent peace will not be laid ${ }^{31}$.

If the world order was to be permanent it had to consider, apart from the ethnic rule, the strategic, economic and historical interests, compensation for historical wrongdoings, punishments for aggression, occupation and loss of human life and material resources. Therefore the Eastern Prussia was to be incorporated into the territory of Poland despite being inhabited primarily by Germans. The idea of justice imposed on the leading nation the obligation to respect the territory, culture and national existence of smaller states but did not prohibit grouping, or a times even demanded political integration of smaller states for their own good. „Polska Zbrojna Moralnie” magazine justified this claiming that it is the most important that grouping and incorporating given nations into a political union should not be accompanied with territorial re-allocations violating ethnographic borders within federation for the benefit and at the expense of other nations ${ }^{32}$. However, in this case the magazine also did not rule out exceptions but these exceptions should result from the legitimate strategic and economical necessities or reasons of safety - matters important for the entirety of the federated region. The leading nation of the federation should resist the temptation to control and interfere in the life of individual members of the federation. The leading nation could not play the role of police imposing its will by strength or threat

\footnotetext{
31 Ibidem, p. 10.

32 Ibidem, pp. 10-11.
} 
of applying force. In arbitrating disputes between the parties or with neighbors the leading country should take into consideration their opinions and follow the law and justice or otherwise the leading country would become loathed. The obligation of the leading nation was to care for own interests and interests of federation partners, neighboring states and general and universal weal in international relations. Execution of the legitimate and justifiable laws should have been conducted in moderation and the ability to compromise or even to make certain sacrifices for the benefit of weaker states. As an example „Polska Zbrojna Moralnie” indicated the region of Śląsk Zaolziański which in historical and ethnic terms should belong to Poland but was also an object of justified claims on the part of Czech Republic. The magazine regretted that Poland enforced its right to this territory on Czechoslovakia simultaneously with aggressive movements of Germany and thus contributed to the partitioning of Czechoslovakia. It constituted a major political and strategic error. The pre-war Polish government acted like an undertaker, wrestling the debt away even if it was to lead to the debtor's demise $e^{33}$.

To the accusations made by members of the National Camp claiming that through his moral rules the Knight's Order of Cross and Sword debilitated Polish fighting spirit the Order responded that Poland on its way to greatness could not follow the examples of imperialistic, materialistic and anti-Christian Germany and USSR ${ }^{34}$. After the outbreak of the German-Russian hostilities in the June of 1941 numerous conspiratorial organizations made grand geopolitical plans concerning Central and Eastern Europe counting on the defeat and dissolution of the USSR, exhaustion of the German war-machine in the East and the decisive victory of Western powers. The Knight's Order of Cross and Sword warned these organizations against wildly fantasizing about wide borders of the post-war Poland, grand international unions or the Central Europe order established only in the interest of Poland, without meeting expectations of its neighbors. In turn, the magazine did allow conspiratorial organizations to draw up new Polish borders on historically Polish lands because Poland had right and duty to strive for incorporation of Belorussian and Ukrainian territories into the Polish political system. However, it is a political nonsense and a moral crime to trim all our neighbors piece by piece. Establishing borders of our country in such manner would not bring definite and permanent peace. These borders would not be the result of an agreement and accord but the evidence of the strength of our bayonets. It would be against Polish political custom and Christian morality. "Polska Zbrojna Moralnie" magazine criticized the designs to divide Czechoslovakia (giving over Ruś Podkarpacka region to Hungary, granting Slovakia independence), partially partition Romany, expand Hungarian territory with Romanian and Slovakian lands, incorporate Lithuania and Moldova into Poland in order to form Polish-Bulgarian border or to release Caucasian nations from under Soviet rule appearing in underground press. Therefore the magazine warned:

Let us be moderate in our dreams and aspirations in order to be able to realize them because a dream is the enemy of reality and may oppose the reality in the future.

The Knight's Order of Cross and Sword emphasized that all Central Europe concepts and the expansion of Polish borders could not proceed regardless of the interests of neighboring nations. If Poland wished to cooperate with them in harmony it must have followed the rule of law and justice. He claimed that the Central Europe was dominated by three great

\footnotetext{
33 Ibidem, p. 11.

34 Czyśmy przeżyli klęskę, „Polska Zbrojna Moralnie”, 31 VII 1942, nos. 5-6, pp. 4-6.
} 
nations - Polish, German and Russian. Germans and Russians disregarded their neighbors and followed the route of national egoism and rapacity. They imposed their national interests by use of military might which resulted in the outbreak of the World War II. Despite its past mistakes only Polish nation could become a champion and dispenser of love, justice and freedom, today, just as it had became one in the past ${ }^{35}$. To follow through with its historic mission and establish order and peace among all nations in the region Poland had to follow the law, justice and Christian morality. As a great nation of Central Europe it had the potential to lead others but not through emulating German and Russian imperialism. Poland did not have the right to deny anyone's freedom and own state but it was not obliged to facilitate this process such as in the case of, for instance, citizens of Byelorussia and Ukraine. The Knight's Order of Cross and Sword cautioned that Lithuanians, Byelorussians and Ukrainians pushed for independence and not for federation with Poland. The organization did not support the idea of a federation. They championed the idea of political and economical bloc uniting Central Europe states following the Christian ideology. The role of Poland was to become a political and moral leader of the Central Europe Bloc regarding and respecting the interests of its individual members.

\section{International order in the ideology of the Knights' Order of Cross and Sword during the Second World War Summary}

During the Second World War The Military Order of the Cross and the Sword combined Catholic moral principles with patriotism in the active struggle for independence. The role of enlarged strategically Poland was peaceful integration of Central Europe. They planned to follow rules of peaceful Catholic international cooperation. Anti- Christian systems of Germany and the USSR and materialistic western countries were not acceptable.

Keywords: The Knight's Order of the Cross and the Sword, The Magazine: „Polska Zbrojna Moralnie" Catholic universalism; Catholic moral principles; just war; Central--European federation

About the author: Dariusz Miszewski, Ph. D., a historian and a graduate of the University of Wrocław, adjunct in the International Relations faculty in the Institute of Political Science at the University of Zielona Góra (1999-2013), he specialized in the subjects of PolishCzechoslovakian and Polish-Czech relations in the 20th and 21st century, national minorities in the Central Europe and Polish political thought of the 20th century.

35 Pokój narodom dobrej woli, „Polska Zbrojna Moralnie”, 24 XII 1941, no. 3, p. 12. 